Kaitlyn Grant

University of Alberta, Edmonton, AB, Canada

\title{
Affective Collections: Care Practices in Digital Community Archives
}

\begin{abstract}
:
This paper will present the literature, theoretical framework, and preliminary findings of my MLIS/MA thesis. My research explores how digital community archives use participation-based methods to build a feminist ethics of care into the archival process. These participation-based methods encourage community members to contribute to the collecting, describing, and creating of records. I will use thematic analysis and critical discourse analysis to explore communitymade content associated with the Flin Flon Heritage Project and Harvest Moon Oral History. I am specifically exploring how community archives could enact an ethics of care through the use of care practices in a digital environment.
\end{abstract}

\section{Introduction}

How do digital community archives provide opportunities to build affective collections? In this research, I am investigating how digital community archives build affective collections through community participation in the archival process. More specifically, I am exploring how community participation builds a feminist ethics of care into the archival process by encouraging participation-based methods of collecting, describing, and, in some cases, creating records. This paper will highlight my ongoing MA and MLIS research on community archives, digital storytelling, and care practices. As a part of my research I will develop two case studies: the Flin Flon Heritage Project (http://flinflonheritageproject.com/) and Harvest Moon Oral History (http://www.harvestmoonoh.com/).

Community archives are collections of records gathered by community members for the purposes of preserving them. It is important to note that the community members also maintain some level of control over the use of the records. By focusing on collections and the designated spaces that are developed by, and for, community members it is possible to explore how these two community archives use care-based preservation practices (Flinn, Stevens, \& Shepard, 2009, p.73). This definition encourages an investigation of how these digital collections work outside of traditional archival practices to better reflect a community or provide a space that meets community-specific needs.

The selected case studies are rooted in the above definition of community archives. The Flin Flon Heritage Project follows the participatory model. The collection is made up of records from the Flin Flon Archives as well as the records of community members, which have all been digitized and added to the community-run website. The community members interact with digital records through social media by identifying places and people in photos and sharing stories or memories inspired by the records. Thus, it meets the above criteria because most of the description work is in the hands of the community members. 
Harvest Moon Oral History is organized by an active community group that created a digital space for participatory oral history that aims to gather stories from community members about the town. It also provides an opportunity to explore digital community heritage work from a Digital Humanities perspective because of the tools it uses, such as GIS StoryMap (https://www.arcgis.com/apps/MapJournal/index.html?appid=48ebc07424304032b848e12c3595f 310). Both case studies offer an opportunity to explore how technology has encouraged the development of community-led initiates that create "'thick description' histories which include the lives, memories and experiences of various communities which would otherwise be very difficult to obtain" (Flinn, 2009, p. 48).

By grounding this research in the theoretical frameworks of feminism and ethics of care, I will use a variety of interdisciplinary methods to explore the two case studies at hand. These methods include an environmental scan of the current landscape of Canadian community archives and discourse analysis to analyze and compare the community-made content to determine how community archives build an ethics of care. As a part of my thesis, the two case studies will provide in depth examples of how different communities participate in the archival or historical process; however, for the purposes of this paper I will provide an overview of the literature and review the methods I have used so far to explore this topic. Finally, I will offer a preliminary look at the analysis process of my research by providing an example of one of my case studies.

\section{Community Archives}

There is growing collection of literature surrounding community archives as scholars investigate the lack of diverse representation in mainstream archival structures. Research efforts in the United Kingdom and the United States have provided some insight on the development of these autonomous archives, which are often formed in opposition to institutional archives like Library and Archives Canada (See Flinn, Stevens, \& Shepard, 2009; Caswell, Migoni, Geraci, \& Cifor, 2016; Zavala, Migoni, Caswell, Geraci, \& Cifor, 2017). Archivist Rebecca Sheffield (2017) explores the history of community archives from a political perspective, highlighting that community archives are formed in response to social movements or grow from other forms of community activism (p. 369). For example, the Lesbian Herstory Archive emerged from the 1960's liberation movement but was "grew first as a personal collection nurtured and cared for in its founders' own apartment" (Sheffield, 2015, p. 312). Furthermore, participatory culture engages community members in the archival process with "low barriers to artistic expression and civic engagement, and participants are encouraged to create knowledge using extant resources and share this knowledge with others in order to achieve a common goal" (Sheffield, 2015, p. 363). Participatory archives are even more relevant in the digital environment, as physical barriers to developing and maintaining collections are removed.

Community archives have existed since the twentieth century, but the development of new technologies enable collections to reach broader audiences and community members that are outside the immediate geographical location, thus expanding the scope of collections. For example, Caswell and Mallick (2014) explore the uses of digital technologies to preserve microhistories of South Asian immigrants to the United States as a part of the South Asian American Digital Archive (p. 83). The archive's mandate focuses on participatory projects that are able to represent groups or communities excluded from traditional archives by preserving records outside of traditional archival practices, including ephemera and oral histories. Alexandra Eveleigh (2017) furthers this discussion by exploring how technology effects the type of work 
done by community archives, highlighting that there are multiple models of participatory archives, each using a unique methodology that extends community involvement in the project. Thus, it much be acknowledged that there is a participation continuum in community work, which makes it difficult to develop concise 'best practice' for the field. Nonetheless, this expansion of the conversation of community archives will be crucial for my research, as it creates an opportunity to look at the contributions of different organization to the preservation of a community's stories.

\section{Digital Storytelling}

Digital storytelling emerged in 1980's as a form of oral history dedicated "to empowering and giving voice to individuals and groups traditionally silenced, marginalized, or ignored by mainstream culture" (Clarke \& Adam, 2012, p. 159). Digital storytelling has been shaped by technological advances in both computers and recording equipment, so it encompasses all narrative forms that are created and shared using digital means; oral history recordings, podcasts, and written accounts are just a few examples (Ganley, forthcoming, as cited in Clarke \& Adam 2012). The format and tools used to create digital stories have changed over time, but there is one constant feature, community participation (Hartley \& McWilliam, 2009; Lambert, 2009; Watkins \& Russo, 2009). The participatory nature of digital storytelling encourages individuals and communities to share their stories and provides the tools and training to do so. Burgess (2006) highlights this, stating, "Digital storytelling as a 'movement' is explicitly designed to amplify the ordinary voice. It aims not only to remediate vernacular creativity but also to legitimate it as a relatively autonomous and worthwhile contribution to public culture" (p. 7).

\section{Care Practices in Society}

The role of care in society has been considered in relation to ethics, justice, and feminism since the twentieth century (Gilligan, 1982; Noddings, 2003; Ruddick, 1980; Tronto, 1993), and the discussion continues to evolve today (Jackson, 2014; Nowviskie, 2015). Care practices are a set of actions that reinforce and build relationships between people, communities, and objects, creating a space for members to live, work, and create to the best of their abilities (Gilligan, 1982; Tronto, 1993).

Care practices focus on the relationships between people. Nowviskie (2015) discusses the role of care practices in the Digital Humanities discipline, and, more broadly, the Humanities, by discussing how academics can be more supportive of graduate student development. Her argument, however, can be applied to many contexts as she highlights how care practices aim to reorient a practitioner's understanding in two ways:

[First] ...toward an appreciation of context, interdependence, and vulnerability — of fragile, little things and their interrelation. The second is an orientation ... toward personal, worldly action and response. ("An Ethic of Care")

Thus, Nowviskie echoes the sentiment of care practices by highlighting how a practitioner can enact care in any space by using care practices. For example, a care-based archival approach places the archivist in the caretaker role, focusing on the needs of the records' many relationships and connections, such as subject, creator, and community (Caswell \& Cifor, 2016). Care 
practices provide an opportunity to focus on the relationships, context, and emotions associated with a community's narrative or records.

\section{Ethics of Care}

In community archives literature, the feminist ethics of care approach views archivists as caregivers of records, bound to the creators, subjects, users, and communities involved with the records in their care. This approach "stresses the ways people are linked to each other and larger communities through webs of responsibilities" (Caswell \& Cifor, 2016, p. 28). In order to maintain this approach archivists could employ radical empathy toward the record, the user, and the larger community. Radical empathy is the "ability to understand and appreciate another person's feelings, experience, etc." (as quoted in Caswell \& Cifor, 2016, p. 25). This could be as simple as stocking tissues at the archive or as complex as developing descriptive systems with different levels of access (Cawell \& Cifor, 2016, p. 38). Radical empathy and an ethics of care practice can work hand-in-hand to explore the relationship-based nature of community archives and digital storytelling websites because of the alternative collection and access practices they can offer.

In an ethics of care, significance is placed on the face-to-face act of caring (Bubeck, 1995; Noddings, 1984); however, since technological advances have changed the way humans communicate and share information, there is definite need to examine how care is enacted in new spaces, such as online forums, social media, or digital archives. Using this framework, I will explore how a digital environment influences the development of relationships, whether between archivists and records, storytellers and stories, or online users and digital records or stories, by examining how each group interacts with projects online.

\section{Conclusion}

In conclusion, this paper will explore the current state of the field of community archives by providing an overview of the literature. It will offer a snapshot of the current Canadian landscape of community archives, as well as review the methods used to conduct interdisciplinary research.

In my presentation I will highlight the current standing of my thesis project. Moreover, I will:

- Review the methodology and theoretical frameworks

- Discuss the potential ramifications of the research for community outreach and advocacy

- Provide a preliminary examination of the analysis process 


\section{Reference List:}

Barber, J. F. (2016). Digital storytelling: New opportunities for humanities scholarship and pedagogy. Cogent Arts \& Humanities, 3(1). https://doi.org/10.1080/23311983.2016.1181037

Bubeck, D. (1995). Care, gender, and justice. Oxford: Oxford University Press.

Caswell, M. (2012). SAADA and the Community-Based Archived Model: What is a Community-Based Archives Anyway? Tides Magazine. Retrieved from https://www.saada.org/tides/article/20120418-704.

Caswell, M. (2014). Toward a survivor-centered approach to records documenting human rights abuse: lessons from community archives. Archival Science, 14(3-4), 307-322. https://doi.org/10.1007/s10502-014-9220-6

Caswell, M. \& Mallick, S. (2014). Collecting the easily missed stories: digital participatory microhistory and the South Asian American Digital Archive. Archives and manuscripts, 42(1): 73-86.

Caswell, M. \& Cifor, M. (2016). From human rights to feminist ethics: Radical empathy in the archives. Archivaria, 81, 23-43. Retrieved from https://archivaria.ca/index.php/archivaria/article/view/13557

Caswell, M., Migoni, A.A., Geraci, N. \& Cifor, M. (2016). 'To Be Able to Imagine Otherwise': A Framework for Understanding the Impact of Community Archives. Archives and records, 38(1), 5-26. https://doi.org/10.1080/23257962.2016.1260445

Clarke, R., \& Adam, A. (2012). Digital storytelling in Australia: Academic perspectives and reflections. Arts and Humanities in Higher Education, 11(1-2), 157-176. https://doi.org/10.1177/1474022210374223

Eveleigh, A. (2017). Participatory Archives. In MacNeil, H. \& Eastwood, T. (Eds). Currents of archival thinking (2nd ed.), (pp. 299-326). Santa Barbara, CA: Libraries Unlimited.

Fisher, B. \& Tronto, J. (1990). "Toward a feminist theory of caring," in Abel, E. K, \& Nelson, M. K. (Eds.), (pp. 35 - 62). Circles of care: Work and identity in women's lives. Albany, N.Y.: State University of New York Press.

Flinn, A. (2007). Community Histories, Community Archives: Some Opportunities and Challenges. Journal of the Society of Archivists, 28 (2), 151-176. https://doi.org/10.1080/00379810701611936

Flinn, A. (2010). Independent community archives and community-generated content: Writing, saving and sharing our histories. Convergence, 16 (1), 39-51. doi: $10.1177 / 1354856509347707$

Flinn, A., Stevens, M., \& Shepard, E. (2009). Whose Memory, Whose Archives? Independent Community Archives, Autonomy, and the Mainstream. Archival Science, 9, 71-86. https://doi.org/10.1007/s10502-009-9105-2

Gilligan, C. (1982). In a different voice. Cambridge, MA: Harvard University Press.

Hartley, J., \& McWilliam, K. (2009). Computational Power Meets Human Contact. In J. Hartley \& K. McWilliam (Eds.), Story circle: Digital storytelling around the world (pp. 1-15). Oxford, UK: Wiley-Blackwell. https://doi.org/10.1002/9781444310580.ch1

Kelleher, C. (2017). Archives Without Archives: (Re)Locating and (Re)Defining the Archive Through Post-Custodial Praxis. Journal of Critical Library and Information Studies, 1(2). https://doi.org/10.24242/jclis.v1i2.29

Kumbier, A. (2014). Ephemeral material: Queering the archive. Sacramento, CA: Litwin Books. Lambert, J. (2009). Where It All Started: The Center for Digital Storytelling in California. In J. Hartley \& K. McWilliam (Eds.), Story circle: Digital storytelling around the world (pp. 
79-90). Oxford, UK: Wiley-Blackwell. Retrieved from http://doi.wiley.com/10.1002/9781444310580.ch1

Lingel, J. (2013, November 5). This is Not An Archive. Retrieved from http://jessalingel.tumblr.com/post/66108958850/this-is-not-an-archive

McCracken, K. (2015). Community Archival Practice: Indigenous Grassroots Collaboration at the Shingwauk Residential Schools Centre. The American Archivist, 78(1), 181-191. https://doi.org/10.17723/0360-9081.78.1.181

Meadows, D., \& Kidd, J. (2009). "Capture Wales”: The BBC Digital Storytelling Project. In Story circle: Digital storytelling around the world (pp. 91-118). Oxford, UK: WileyBlackwell. Retrieved from http://doi.wiley.com/10.1002/9781444310580.ch6

Moore, S., \& Pell, S. (2010). Autonomous archives. International journal of heritage studies 16(4), 255-68. https://doi.org/10.1080/13527251003775513

Noddings, N. (2003). Caring: A feminist approach to ethics and moral education. 2nd edition. Berkeley, CA: University of California Press.

Nowviskie, B. (2015, October 4). On capacity and care. Nowviskie.org. Retrieved from http://nowviskie.org/2015/on-capacity-and-care/

Ruddick, S. (1998). Care as labor and relationship in Haberm J.C .\& Halfon, M.S.. Norms and values: Essays on the work of Virginia Held. (Eds.), (pp. 3 - 26) Lanham, Md.: Rowman and Littlefield.

Ruddick, S. (1980). Maternal Thinking. Feminist Studies, 6(2 (Summer)), 342-367.

Ruddick, S. (1990). Maternal thinking: Toward a politics of peace. New York: Ballantine Books.

Sander-Staudt, M. (n.d.). Care Ethics. Retrieved March 11, 2019, from https://www.iep.utm.edu/care-eth/

Sheffield, R. (2015). The Emergence, Development and Survival of Four Lesbian and Gay Archives (Doctor of Philosophy). University of Toronto, Toronto, ON.

Sheffield, R. (2017). Community Archives. In MacNeil, H. \& Eastwood, T. (Eds). Currents of archival thinking (2nd ed.), (pp. 351-376). Santa Barbara, CA: Libraries Unlimited.

Simondson, H. (2009). Digital Storytelling at the Australian Centre for the Moving Image. In J. Hartley \& K. McWilliam (Eds.), Story circle: Digital storytelling around the world (pp. 118-123). Oxford, UK: Wiley-Blackwell. https://doi.org/10.1002/9781444310580.ch6

Stake, R. E. (1995). The Art of Case Study Research. Thousand Oaks, CA: SAGE Publications, Inc.

Tronto, J. C. (1993). Moral boundaries: A political argument for an ethic of care. New York: Routledge.

Watkins, J., \& Russo, A. (2009). Beyond Individual Expression. In J. Hartley \& K. McWilliam (Eds.), Story circle: Digital storytelling around the world (pp. 269-278). Oxford, UK: Wiley-Blackwell. https://doi.org/10.1002/9781444310580.ch20

X, A., Campbell, T., \& Stevens, M. (2009). Love and lubrication in the archives, or rukus!: A black queer archive for the United Kingdom. Archivaria, 68, 271-294. Retrieved from https://archivaria.ca/index.php/archivaria/article/view/13240/14558

Zavala, J., Migoni, A.A., Caswell, M., Geraci, N. \& Cifor, M. (2017). 'A process where we're all at the table': Community archives challenging dominant modes of archival practice. Archives and manuscripts, 45(3), 202-215. https://doi.org/10.1080/01576895.2017.1377088 